\title{
The Use of Ex Curia Experts in International Litigation: Why the WTO Dispute Settlement Cannot Serve to Improve ICJ Practice
}

\author{
Andrea Hamann"
}

\section{Introduction}

The practice of international courts and tribunals regarding the establishment of the facts has drawn increasing attention, in particular in complex cases requiring expert consultation. ${ }^{1}$ The spotlight focused on the Interna-

* Professor of Public Law at the University of Strasbourg.

1 One of the first studies of the recourse to expertise in international adjudication is G. White, The Use of Experts by International Courts (1965). More recently, see J. G. Devaney, Fact-Finding before the International Court of Justice (2016); M. M. Mbengue, R. Das, The ICJ's Engagement with Science: To Interpret or Not to Interpret?, 6 J. Int. Disp. Settlement (2015), 1, 568; J. D’ Aspremont, M. M. Mbengue, Strategies of Engagement with Scientific Fact-finding in International Adjudication, 5 J. Int. Disp. Settlement (2014), 1, 240; D. Peat, The Use of Court-Appointed Experts by the International Court of Justice, BYBIL (2014), 1, 271; C. E. Foster, New Clothes for the Emperor? Consultation of Experts by the International Court of Justice, 5 J. Int. Disp. Settlement (2014), 1, 139 [New Clothes]; C. E. Foster, Science and the Precautionary Principle in International Courts and Tribunals - Expert Evidence, Burden of Proof and Finality, Cambridge Studies in Int. and Comp. Law (2011); J. G. Sandoval et al., Adjudicating Conflicts Over Resources: The ICJ's Treatment of Technical Evidence in the Pulp Mills Case, 3 Goettingen J. Int. L. (2011), 1, 447; F. R. Jacur, Remarks on the Role of Ex Curia Scientific Experts in International Environmental Disputes, in N. Boschiero et al., International Courts and the Development of International Law - Essays in Honour of Tullio Treves (2013), 441; Y. Fukunaga, Experts in WTO and Investment Litigation, in J. A. Huerta-Goldman et al., WTO Litigation, Investment Arbitration, and Commercial Arbitration (2013); Standard of Review and 'Scientific Truths' in the WTO Dispute Settlement System and Investment Arbitration, 3 J. Int. Disp. Settlement (2012), 1, 559; S. El Boudouhi, L'élément factuel dans le contentieux international (2013); M. M. Mbengue, International Courts and Tribunals as Fact-Finders: The Case of Scientific Fact-Finding in International Adjudication, 53 Loy. L.A. Int'l \& Comp. L. Rev. (2011), 53 [International Courts]; J. Ngambi, La preuve dans le règlement des différends de l'Organisation mondiale du commerce (2010), 326; M. T. Grando, Evidence, Proof, and Fact-Finding in WTO Dispute Settlement (2009); J. Rios Rodrigues, L'expert en droit international (2009); H. Ruiz Fabri, J. M. Sorel (eds.), La 
tional Court of Justice after its judgment in the Pulp Mills case, ${ }^{2}$ which triggered abundant commentary and criticism from scholars, in the wake of the strong joint dissenting opinion of Judges Al-Khasawneh and Simma. While previous cases had already raised concern about the ICJ's fact-finding methods, this particular dispute evidently constitutes a landmark in the reflexion on how international courts and tribunals ascertain the facts, more specifically on the use of experts in international litigation. The more recent Whaling in the Antarctic case only brought this issue to the forestage once more. ${ }^{3}$ Judges Al-Khasawneh and Simma wrote that:

$[\mathrm{T}]$ he task of a court of justice is not to give a scientific assessment of what has happened, but to evaluate the claims of parties before it and whether such claims are sufficiently well-founded so as to constitute evidence of a breach of a legal obligation. In so doing, however, the Court is called upon 'to assess the relevance and the weight of the evidence produced in so far as is necessary for the determination of the issues which it finds it essential to resolve. ${ }^{4}$

This pinpoints the crux of the problem: the function of any court or tribunal, whether judicial or arbitral, domestic or international, is to settle disputes by applying the relevant legal rules to the relevant facts. Unquestionably this is, on the whole, a legal operation, and yet it contains an inherently and irreducible extra-legal aspect, i.e., the establishment of the facts. It is this challenging task of establishing and assessing the facts that has increasingly drawn attention, because of the daunting difficulty it raises in disputes that present great factual complexity, all the more so when they touch on scientific or technical issues. It is self-evident that a compe-

preuve devant les juridictions internationales (2007); E. Truilhe-Marengo, L'expertise scientifique dans les contentieux internationaux: l'exemple de l'OMC, in SFDI, Le droit international face aux enjeux environnementaux (2010), 207; Sh. Rosenne, Fact-Finding before the International Court of Justice, in Sh. Rosenne, Essays on International Law and Practice (2007), 235; L. Savadogo, Le recours des juridictions internationales à des experts, Annuaire français de droit international (2004), 231.

2 Pulp Mills on the River Uruguay (Argentina v. Uruguay), Judgment, ICJ Reports 2010, 14.

3 Whaling in the Antarctic (Australia v. Japan), Judgment, ICJ Reports 2014, 226.

4 Pulp Mills on the River Uruguay, supra note 2, 108, paras. 4,5, Joint dissenting opinion of Judges Al-Khasawneh and Simma, quoting Sh. Rosenne, The Law and Practice of the International Court of Justice, 1920-2005, vol. III, $4^{\text {th }}$ ed. (2012), 1039. But, see also Pulp Mills on the River Uruguay, supra note 2, Opinion and declarations of Judges Yusuf and Cançado Trindade, and of Judge ad hoc Vinuesa. 
tent legal ruling can only be passed if the facts in dispute are established and thereby known; ${ }^{5}$ knowledge, however, implies comprehension and the difficulty therefore lies beforehand: bluntly phrased, in order to correctly establish the facts, a court must first and foremost understand them. This essential task was framed by the ICJ in the following words:

It is the responsibility of the Court, after having given careful consideration to all the evidence placed before it by the Parties, to determine which facts must be considered relevant, to assess their probative value, and to draw conclusions from them as appropriate. ${ }^{6}$

While one cannot but agree, it is nevertheless surprising that this seemingly obvious statement was made in one of the most factually complicated cases the ICJ has yet had to decide. And indeed, as Judges Al-Khasawneh and Simma pointed out, the fact is that "the Court of its own is not in a position adequately to assess and weigh the complex scientific evidence presented by the Parties", while Judge ad hoc Vinuesa emphasized the "lack of specialized expert knowledge" of the Court. ${ }^{7}$ The Pulp Mills case thus shed a crude light on the Court's traditional fact-finding methods, questioning their suitability given the increasing complexity of certain cases.

The issue indeed cannot be reduced to disputes involving scientific data alone, although they present the most immediately perceptible challenge for a court of law, whether they are boundary or environmental disputes. But the process of establishing the facts can certainly be daunting in any factually complex case, as was made apparent in the Genocide cases: ${ }^{8}$ not only were the facts abundant and excessively complex, but they were also at a great distance from the Court, both in space and time, as the ICJ ruled on the merits of both cases 16 and 25 years after the events, and after a specialized tribunal had already examined the same events under the light of individual criminal responsibility. Although the question put before the ICJ was the distinct one of State responsibility, these circumstances seem to have placed the Court in an awkward position, and it chose to heavily rely

5 Rosenne, supra note $1,235$.

6 Pulp Mills on the River Uruguay, supra note 2, para. 168.

7 Pulp Mills on the River Uruguay, Joint dissenting opinion of Judges Al-Khasawneh and Simma, supra note 4, para. 4; Pulp Mills on the River Uruguay, supra note 2, 266, para. 71, Dissenting opinion of Judge ad hoc Vinuesa.

8 Application of the Convention on the Prevention and Punishment of the Crime of Genocide (Bosnia and Herzegovina v. Serbia and Montenegro), Judgment, ICJ Reports 2007, 43; Application of the Convention on the Prevention and Punishment of the Crime of Genocide (Croatia v. Serbia), Judgment, ICJ Reports 2015. 
on the facts as established by the ICTY, to the extent that it seemed to systematically extract its own determinations from those previously made. ${ }^{9}$ Thus, the difficulty to unequivocally know the facts can arise in any complex dispute, although the challenge is particularly obvious in cases which call for knowledge in areas outside the law, in which judges are not trained - and, admittedly, should not be expected to be.

What can and should be expected, though, is that individuals with the necessary qualifications fill this gap and assist judges in attaining the required knowledge, and it is for this purpose precisely that experts can be called upon, as acknowledged by the ICJ itself: "the purpose of the expert opinion must be to assist the Court in giving judgment upon the issues submitted to it for decision". 10 The operative word "assist" clarifies from the onset that the autonomy of the adjudicating body remains intact, and in particular that calling upon experts does not imply a delegation of the decision-making power, but on the contrary that the expert's report or opinion can or should serve only as a basis to clarify the court's own evaluation of the facts. ${ }^{11}$ Such assistance may indeed seem inevitable in certain circumstances, to the extent that settling a dispute is intrinsically a matter of translation from one "language" into another: by applying the relevant rules to the facts, a factual situation will be declared by the judge to consti-

9 A. Hamann, L'arrêt de la CIJ du 3 février 2015 dans l'affaire du Génocide (Croatia v. Serbia), Annuaire français de droit international (2015), 201; A. Gattini, Evidentiary Issues in the ICJ's Genocide Judgment, 5 J. Int. Criminal Justice (2007), 889. While C. Tams analyses this as an "elegant way for the Court to arrive at a satisfactory assessment of evidence in cases involving complex questions of fact”, J. E. Alvarez has a harsher appreciation of this practice, which he calls an "out-sourcing" of the fact-finding process. See Ch. J. Tams, Article 50, in A. Zimmermann et al. (eds.), The Statute of the International Court of Justice - A Commentary (2012), 1290-1291; and J. E. Alvarez, Are International Judges Afraid of Science?: A Comment on Mbengue, 34 Loy. L.A. Int'l \& Comp. L. Rev. (2012), 83.

10 Application for Revision and Interpretation of the Judgment of 24 February 1982 in the Case concerning the Continental Shelf (Tunisia/Libyan Arab Jamahiriya), Judgment, ICJ Reports 1985, 228 (emphasis added). The same appears in the WTO dispute settlement system, where the panel explained that it would "undertake [its] examination by assessing the parties' arguments and evidence" in a recent dispute; "We will also support our analysis, as relevant, with the guidance we received through the responses from the experts" (Panel Report, Russia - Pigs (EU), Doc. WT/DS475/R (adopted 19 August 2016), para. 7.416, [emphasis added].

11 While most authors see no breach of the distinction between the function of the adjudicating body and the function of experts, others argue that an increased use of experts would amount to a delegation of the judicial function. See for instance Peat, supra note 1, 289; Rodrigues, supra note 1,15-19. 
tute a legal situation, and the translation thus takes place when the facts brought before the judge are coined into legal terms (qualification) and when, consequently, they are subjected to the identified relevant legal rule (interpretation and application). Although often it is mainly the latter that draws attention, the essential crux of the translation process lies beforehand, in the legally unseizable operation by which the facts are ascertained. On this ascertainment depends the accuracy of the entire translation, but the complexity of the facts or their remoteness from the judge's knowledge can require in itself a preliminary translation, providing a basis for the legal operation. In other words, in certain circumstances experts appear to be the indispensable tools that allow for a correct translation into law. ${ }^{12}$ As the WTO panel in the US/Canada-Continued Suspension phrased it, "the role of the experts [is] to act as an 'interface' between the scientific evidence and the Panel, so as to allow it to perform its task as the trier of fact". ${ }^{3}$ This assistance to the primary "translator" is in substance also the role that the ICJ recognised for experts in the Corfu Channel case, when it explained its decision to seek expert advice "on account of the technical nature of the questions involved".14

But the complexity of a case, while it might be self-evident, is not an objective state. As Gabrielle Marceau and Jennifer Hawkins have acutely pointed out, whether or not judges call upon experts ultimately depends on whether they "recogniz[e] the limits of their own expertise". ${ }^{15}$ And the fact remains that the ICJ has traditionally been reluctant to request experts

12 L. Gradoni even identifies a two-tiered translation process, namely the "encoding" of the parties' claims into scientific language, and the subsequent "decoding" of the scientific language by the experts: L. Gradoni, La science judiciaire à l'OMC ou les opinions du juge Faustroll autour des OGM et de la viande de bovins traités aux hormones, in M. Deguergue, C. Moiroud (eds.), Les OGM en questions - Sciences, politique et droit (2013), 313.

13 Panel Report, United States - Continued Suspension, Doc. WT/DS320/R (adopted 31 March 2008), para. 6.72; Panel Report, Canada - Continued Suspension, Doc. WT/DS321/R (adopted 31 March 2008), para. 6.67.

14 Corfu Channel (Compensation), Judgment, ICJ Reports 1949, 248. See also Corfu Channel, Order, ICJ Reports 1948, 126, 127, where the Court asked the experts to "give the reasons for [their] findings in order to make their true significance apparent to the Court”. The WTO Appellate Body has similarly emphasized that experts are to "help [the Panel] to understand and evaluate the evidence submitted and the arguments made [by the parties]", see Appellate Body Report, Japan Agricultural Products II, Doc. WT/DS76/AB/R (adopted 22 February 1999), para. 130.

15 G.Z. Marceau, J.K. Hawkins, Experts in WTO Dispute Settlement, 3 J. Int. Disp. Settlement (2012), 504. 
to assist them in understanding the evidence, an attitude that has been widely commented on and criticized. This criticism has repeatedly been backed by a comparison with the practice in the dispute settlement system of the World Trade Organization (WTO), where expert consultation is a common feature in the proceedings. It is a tempting comparison indeed, considering that both are world courts, that both settle interstate disputes, and that both are permanently instituted (although WTO panels are appointed on an ad hoc basis).

It is this comparison that the present contribution proposes to address and to question. Judges Al-Khasawneh and Simma in particular observed that other international courts and tribunals have "accepted the reality of the challenge posed by scientific uncertainty in the judicial process", and felt that the WTO dispute settlement system has "most contributed to the development of a best practice of readily consulting outside sources in order to better evaluate the evidence submitted to it". ${ }^{16}$ Many authors since the Pulp Mills case have followed in the reference to the WTO dispute settlement system when expressing criticism of the ICJ practice.${ }^{17}$ It therefore seemed useful to explore whether such comparison can be validly sustained and, if so, whether WTO practice could serve as a "model" for the ICJ regarding the use of experts ex curia.

However, the aim of this paper is not to nourish the criticism of the practice of the ICJ by inversely praising the WTO dispute settlement system, nor to defend the first by inversely understating the practice of the latter. It is undeniable that the ICJ displays an increasingly objectionable reluctance to call upon experts, whereas expert consultation has become almost commonplace in the WTO dispute settlement system. But this alone does not provide grounds for a valid comparison. The purpose of this paper is much more to demonstrate that a relevant comparison is impossible, or at least of limited value. There are indeed two fundamental differences between both judicial systems, which bias any attempted comparison be-

16 Pulp Mills on the River Uruguay, Joint dissenting opinion of Judges Al-Khasawneh and Simma, supra note 4, paras. 15, 16.

17 See for instance M. M. Mbengue, Between Law and Science: A Commentary on the Whaling in the Antarctic Case, Questions of International Law (2015), 11; and Mbengue, International Courts, supra note 1; Peat, supra note 1, 289; Devaney, supra note 1, 130; Sandoval et al., supra note 1, 462-463; R. Moncel, Dangerous Experiments: Scientific Integrity in International Environmental Adjudications after the ICJ's Decision in Whaling in the Antarctic, 42 Ecology Law Quarterly (2015), 317. 
tween the practice of both courts, and which flaw the conclusions one might be tempted to draw.

The first difference is that both courts do not operate in the same settings, and it is argued here that these settings heavily weigh on how they can exercise their powers. While the ICJ has jurisdiction for any dispute regarding the application and/or interpretation of international law in the broadest sense, provided that the parties have given their consent, the WTO dispute settlement system has been tailored as the ultimate tool for safeguarding the rule of law in the international trade regime. As such, it is part of a complex institutional and normative construction, whose main force is provided by its exclusive and compulsory character. ${ }^{18}$ By virtue of the "single undertaking" all WTO Members are equally bound by all multilateral treaties, with limited and heavily-regulated possibilities of opting out. One of these multilateral treaties, the Dispute Settlement Understanding (DSU), does not provide any opting out provision at all, so that all Members are subject to the compulsory jurisdiction of the WTO adjudicative bodies. This remarkable trait of the international trade regime provides its dispute settlement system with a power that the ICJ does not and cannot possess. To the extent that it is essentially dependant on State consent, in many a dispute the politics of the adjudicative process play a role at least as determining as the strictly legal aspect of the judicial function. Bluntly phrased, while WTO decisions might raise concern, criticism, and even open disapproval, the adjudicating bodies nevertheless run little risk of upsetting Members so much that they decide to quit the system; the ICJ on the other hand must constantly be cautious of the delicate balance between what is legally correct and what is politically acceptable. This touches on the different dimensions of the function of settling disputes: the WTO system, due to its compulsory character, can afford to be exclusively legality-oriented and therefore, when establishing the facts, strive to ascertain the truth understood as an objective and therefore irrefutable absolute; the ICJ has to remain more cognizant of State acceptance in order to encourage compliance with the decision, and many a case indeed, especially in boundary disputes, has demonstrated a clear tendency of "transactional" justice. This state of affairs necessarily reflects on the manner in which the judicial bodies approach their task and exercise the powers conferred by their respective statutes.

18 For a succinct presentation of this feature, see R. Yerxa, The Power of the WTO Dispute Settlement System, in R. Yerxa, B. Wilson (eds.), Key Issues in WTO Dispute Settlement (2005), 3-6. 
The second fundamental difference is that the WTO system is twotiered, with panels acting as first instance tribunals and an Appellate Body as appeals court. The ICJ is unburdened by such hierarchy and, consequently, as former US Supreme Court Justice Robert H. Jackson famously wrote:

We are not final because we are infallible, but we are infallible only because we are final. ${ }^{19}$

This doesn't intend to suggest that the ICJ is flippant or less careful in the exercise of its function whereas WTO panels are not. It is meant, however, to emphasize the crucial fact that the exercise of its powers by a panel, including with respect to the determination of the facts, can be contested by the parties on appeal and can thus be subject to "censorship". This puts a considerable strain on panels of which the ICJ is free, and, as will be demonstrated later, the discipline imposed by the appellate review plays a crucial role as far as expert consultation is concerned.

These differences evidently do not prevent the identification of common features and issues, which allow for an examination of the recourse to experts in ICJ and WTO proceedings. The following developments will thus focus on both courts' powers to call upon experts (I), on the actual exercise of these powers (II), and finally on the utilisation of expert evidence (III). Two conclusions derive from this confrontation: first, the divide between both courts regarding the use of experts is not as clear-cut as it may seem on first sight, as some of the objectionable practices at the ICJ also thrive at the WTO. Second, when there is a divide, it can mainly be attributed to the fact that WTO panels operate in a more framed and constrained setting, where any deflection from their statutory obligations can be blamed and addressed by the Appellate Body. Ultimately, it appears that the aforementioned differences between both judicial systems fundamentally shape the exercise of their function, and that they invalidate any comparison that might be drawn between the ICJ and the WTO dispute settlement regarding the use of experts. While it would certainly be a welcome improvement if the ICJ departed from its traditional methods of establishing the facts and didn't shy away from seeking expert advice, such improvement is unlikely to be usefully inspired by WTO practice.

19 Brown v. Allen, 344 U.S. 443 (1953), concurrent opinion of Justice Jackson, p. 540. 


\section{The power to seek expert advice}

Both the ICJ and WTO panels are enabled, in broad terms, to establish the facts of a case. ${ }^{20}$ Their statutes vest them with explicit and specific powers to call upon experts, whose proper identification as such (A) is crucial in order to protect the parties' due process rights (B).

\section{A. Identification and status of experts}

In practice a large variety of experts have been identified by scholars court-appointed, party-appointed, expert counsel, "ghost" experts, and assessors $^{21}$ - but only court-appointed and party-appointed experts are recognized by the ICJ Statute and, to a lesser extent, by the WTO agreements, ${ }^{22}$ notwithstanding the variety of names given to experts and expert bodies in the WTO treaties. Regarding the ICJ, the only provision making room for ex curia experts is the broadly termed Article 50 of the Statute, according to which "the Court may, at any time, entrust any individual, body, bureau, commission, or other organization that it may select, with the task of carrying out an enquiry or giving an expert opinion",23 court-appointed experts being crucially considered to be independent. ${ }^{24}$

20 It can certainly be argued that even if specific provisions are absent, any court or tribunal has inherent fact-finding powers, as an intrinsic and implied element of its judicial function. See White, supra note 1, 73.

21 On these five categories, see for instance Foster, New Clothes, supra note 1, 139; L. C. Lima, The Evidential Weight of Experts before the ICJ: Reflections on the Whaling in the Antarctic Case, 6 J. Int. Disp. Settlement (2015), 628-630; Savadogo, supra note $1,231$.

22 Ex parte experts are recognized by Article 43 para. 5 of the ICJ Statute, according to which " $[\mathrm{t}]$ he oral proceedings shall consist of the hearing by the Court of witnesses, experts, agents, counsel, and advocates", and this provision is complemented by Articles 57 and 64 of the Rules (see S. Talmon, Article 43, in A Zimmermann et al. (eds.), The Statute of the International Court of Justice - A Commentary (2012), 977). They are not recognized or even mentioned as such in the DSU or the panels' Working Procedures, which may seem curious - but then again neither is there any provision concerning the composition of parties' delegation or the types of evidence submitted.

23 Article 50 of the Statute is complemented by Article 62 para. 2 of the Rules of Court. On the practical irrelevance of the distinction between enquiries and expert opinion, see Tams, supra note 9, 1289.

24 In addition the ICJ is empowered by Articles 9 and 21 of the Rules of Court to appoint assessors, who take part in the deliberations but do not vote (Article 9 
WTO provisions, on the other hand, contain great variety regarding ex curia experts, making room for individual expertise, groups of experts and even institutional expertise. The general provision, however, is similar to Article 50 of the ICJ Statute, and arguably even wider. Article 13 DSU indeed confers vast investigative powers to panels, by providing that:

Each panel shall have the right to seek information and technical advice from any individual or body which it deems appropriate. [...] 2. Panels may seek information from any relevant source and may consult experts to obtain their opinion on certain aspects of the matter. With respect to a factual issue concerning a scientific or other technical matter raised by a party to a dispute, a panel may request an advisory report in writing from an expert review group [...] (emphasis added).

The distinction between individual and group expertise by "expert review groups" (ERGs) is an important one, in principle at least, as ERGs are specifically dealt with in Appendix 4 of the DSU; according to the Appellate Body its provisions are only applicable to ERGs and do not bind the panel if it chooses to appoint individual experts instead of an ERG. ${ }^{25}$ The decision to use individual experts or to establish a group is left "to the sound discretion of a panel”, ${ }^{26}$ and, in fact, no ERG has been appointed in over twenty years of practice. ${ }^{27}$

para. 1 and 21 para. 2 of the Rules of Court); however, assessors do not provide an expert opinion and are therefore to be distinguished from ex curia experts. It should also be noted that, by virtue of Article 26 para. 1 of its Statute, the ICJ created a permanent Chamber for Environmental Matters in 1993, but it has been inactive so far as no parties in any environmental dispute have ever referred their case to this Chamber. Consequently, whereas its composition was periodically renewed until 2006, the ICJ decided not to hold elections in 2006.

25 Appellate Body Report, EC - Hormones, Docs. WT/DS26/AB/R, WT/DS48/AB/R (adopted 16 January 1998), para. 148. For a comparative analysis of individual expertise and ERGs, see M. Cossy, Panels' Consultation with Scientific Experts: The Right to Seek Information under Article 13 of the DSU, in R. Yerxa, B. Wilson (eds.), Key Issues in WTO Dispute Settlement (2005), 209-212; T. Christoforou, Settlement of Science-Based Trade Disputes in the WTO: A Critical Review of the Developing Case Law in the Face of Scientific Uncertainty, 8 N.Y.U. Environmental Law Journal (2000), 637-641.

26 Appellate Body Report, EC - Hormones, supra note 25, para. 147.

27 See for instance the US/Canada - Continued Suspension cases, where the EU had explicitly suggested the establishment of an ERG but the panel instead decided to consult individual experts, Panel Reports, US - Continued Suspension, supra 
Notably, other WTO treaties also specifically provide for expert consultation: According to Article 11 para. 2 of the Agreement on Sanitary and Phytosanitary Measures (SPS Agreement), a panel should seek expert opinion in disputes that involve "scientific or technical issues", and may establish an "advisory technical expert group"; Article 14 para. 2 of the Agreement on Technical Barriers to Trade (TBT Agreement) provides that a panel can establish a "technical expert group to assist in questions of a technical nature, requiring detailed consideration by experts"; and the Agreement on Subsidies and Countervailing Duties (SCM Agreement) enables panels in subsidy disputes to "request the assistance of the Permanent Group of Experts" (Article 4.5). ${ }^{28}$ Whether there is a distinct difference between this Permanent Group of Experts (PGE) and the ERGs under Article 13 DSU is uncertain; the only perceptible difference is that a PGE is permanent and has a predetermined specialized competence while an ERG will be established ad hoc, with varying technical competence. However, like the ERGs, a PGE has not once been called to serve.

Finally, several treaties also provide for institutional expertise. While every WTO agreement is flanked by a committee in charge of administering it, ${ }^{29}$ the Agreement on Customs Valuation has the particular feature of providing for the establishment of an additional committee, the Technical Committee on Customs Valuation, which exists and operates under the auspices not of the WTO but of the World Customs Organization (Article 18 para. 2). The Technical Committee can serve in itself as an expert in judicial proceedings, as a panel may request it to "carry out an examination of any questions requiring technical consideration" (Article 19 para. 4). Finally, outside institutional consultation is specifically provided for in the

note 13, para. 7.71; and Canada - Continued Suspension, supra note 13, para. 7.69.

28 This PGE, pursuant to Article 24.3, was established by the SCM Committee and is composed of five "independent persons, highly qualified in the fields of subsidies and trade relations".

29 To a certain extent it can even be argued that these committees in themselves constitute expert bodies, all the more so since the Appellate Body has held that their deliberations and conclusions, when relevant, should be taken into account by panels. See Appellate Body Report, India - Quantitative Restrictions, Doc. WT/ DS90/AB/R (adopted 23 August 1999), para. 103: "We are cognisant of the competence of the BOP Committee and the General Council with respect to balance-ofpayments restrictions under Article XVIII para. 12 of the GATT 1994 and the BOP Understanding. [...] Moreover, we are convinced that, in considering the justification of balance-of-payments restrictions, panels should take into account the deliberations and conclusions of the BOP Committee" [emphasis added]. 
SPS Agreement, according to which panels may "consult the relevant international organizations" (Article 11 para. 2), ${ }^{30}$ and in GATT Article XV para. 2, according to which the IMF shall be consulted in all cases concerning "monetary reserves, balances of payments or foreign exchange arrangements".31

This succinct overview shows that although WTO provisions are more numerous and detailed than those regarding the ICJ, they provide the same possibilities for expert consultation, and evidently neither statute makes room for experts who are not appointed either by the court or the parties. This, in turn, has important consequences since guarantees of good administration of justice are attached to the recognized categories of experts.

\section{B. Due process rights}

These guarantees, indeed, have been tailored for the only two categories of experts recognized by the ICJ Statute and the WTO agreements. ICJ provisions present few details, with no requirement regarding the specific technical or scientific issue calling for expertise, nor the expert selection process itself. ${ }^{32}$ Significantly, the selection process is much more constrained by the WTO agreements. While only the SPS Agreement obliges the panel to consult with the parties, ${ }^{33}$ the general practice is nevertheless for such

30 Those expressly mentioned in the Agreement are the Codex Alimentarius Commission, the International Office of Epizootics and the Secretariat of the International Plant Protection Convention in cooperation with regional organizations operating within the framework of the International Plant Protection Convention.

31 However, it must be noted that Article XV para. 2 of the GATT addresses WTO Members and not panels as such. But when the circumstances referred to in Article $\mathrm{XV}$ arise in judicial proceedings, arguably the panel will have a similar duty to request such expert consultation, under the general provision of Article 13 DSU.

32 But see Article 51 of the Statute: "If the Court considers it necessary to arrange for an enquiry or an expert opinion, it shall, after hearing the parties, issue an order to this effect, defining the subject of the enquiry or expert opinion, stating the number and mode of appointment of the persons to hold the enquiry or of the experts, and laying down the procedure to be followed. Where appropriate, the Court shall require persons appointed to carry out an enquiry, or to give an expert opinion, to make a solemn declaration".

33 Except when the panel wishes to establish an ERG and to appoint citizens of parties to the dispute, in which case all parties must consent (DSU Appendix 4, para. 3). 
consultation to take place (which extends to the drafting of the questions submitted to the experts). ${ }^{34}$ Specific rules for ERGs under Article 13 para. 2 DSU are set out in Appendix 4 (the rules for TBT experts are tailored identically), and a particularly noteworthy feature is the existence of overarching Rules of Conduct for the dispute settlement. ${ }^{35}$ These apply to all experts appointed under the DSU, and the SCM, SPS, and TBT Agreements. ${ }^{36}$ Only the Agreement on Customs Valuation is carved out, which is consistent with the fact that its Technical Committee on Customs Valuation is established under the auspices of the World Customs Organization and not the WTO. All covered experts are subject to the governing principle that they shall be "independent and impartial, shall avoid direct or indirect conflicts of interest and shall respect the confidentiality of proceedings of bodies pursuant to the dispute settlement mechanism", and they have corresponding disclosure and confidentiality obligations. ${ }^{37}$ These requirements equally oblige panels, considering that the experts' independence and impartiality directly pertain to the due process rights of the parties to the dispute. The Appellate Body has indeed held that the "[...] due process protection applies to the process for selecting experts and to the panel's consultations with the experts, and continues throughout the proceedings", and it does not hesitate to review the panel's selection process in order to determine whether the panel has adequately assessed the disclosed information in order to evaluate the "likelihood that the expert's independence and impartiality may be affected, or if justifiable doubts arise as to the expert's independent or impartiality."38

34 See for instance one of the most recent disputes to date, Russia - Pigs (EU), where the panel requested the assistance of the Food and Agriculture Organization (FAO) and the World Organization for Animal Health (OIE) to suggest possible experts who could assist the panel, but also asked the EU to comment on the experts spontaneously suggested by Russia; the panel also received a list from both parties of their suggested questions to the panel. See Panel Report, Russia - Pigs (EU), supra note 10, paras. 1.18-1.37. See also the Australia - Apples dispute, where the expert selection process was complicated by the repeated objections of the parties to some of the suggested experts: Panel Report, Australia - Apples, Doc. WT/DS367/R (adopted 09 August 2010), paras. 1.21-1.39.

35 Rules of Conduct for the Understanding on Rules and Procedures Governing the Settlement of Disputes, Working Procedures for Appellate Review, Doc. WT/AB/WP/6, (adopted 16 August 2010), Annex II.

36 Ibid., Annex 1B of the Rules of Conduct.

37 Ibid., Section II and III.

38 Appellate Body Report, US/Canada - Continued Suspension, Docs. WT/320/AB/R, WT/DS321/AB/R (adopted 16 October 2008), para. 446. The Appellate Body went on to consider that "[w]here a panel's ability to act as an inde- 
In contrast, the DSU is much more elliptical regarding the examination of experts: apart from the general organization of written submissions, panels' meetings with the parties and rebuttal, it contains no requirements regarding the examination of experts. The only general provision concerns ERGs and specifies that their report shall be submitted to the parties "with a view to obtaining their comments", whereas the panel can put questions to the parties at any time. ${ }^{39}$ In ICJ proceedings the relevant provision is Article 51 of the Statute, which refers to the Rules of the Court and covers both court- and party-appointed experts. ${ }^{40}$ It is quite parsimoniously laid out, since it merely provides that any relevant questions during the hearings "are to be put to the witnesses and experts under the conditions laid down by the Court" in its Rules of procedure. Concerning ex curia experts specifically, the parties are to receive communication of every report and record of an enquiry and of every expert opinion, and "be given the opportunity of commenting upon it" (Article 67 para. 2 of the Rules). This provision is essential in terms of good administration of justice, as it guarantees the transparency of expert consultation and safeguards the parties' due process rights to make observations on the conclusions presented by the experts. In comparison, Article 65 secures these rights much more strongly regarding ex parte experts: not being treated as independent sources of information, they are subject not to mere comments a posteriori but to proper examination by the agents, counsel or advocates of the parties, while the President and the judges can ask questions. ${ }^{41}$ Information presented by party-appointed experts is thus treated much more thoroughly than experts appointed by the Court, which has little to do with securing the parties' equal rights and much more with the fact that information provided by $e x$ parte experts by definition calls for caution.

pendent adjudicator has been compromised, as we have found in this case, this raises serious issues as to whether the panel's findings may be sustained" (para. 484).

39 DSU Appendix 4, para. 6 and 8.

40 Articles 57, 58, 63, 65, 70 and 71 apply to ex parte experts, Articles 67 and 68 to ex curia experts.

41 The provision leaves the concrete process of such examination quite unclear, but practice has at least confirmed that the parties take the lead and that it unfolds in three stages: examination by the party presenting the expert, cross-examination by the other party, and re-examination by the first. See C. Tams, Article 51, in A. Zimmermann et al. (eds.), The Statute of the International Court of Justice - A Commentary (2012), 1306. 
Evidently these procedural guarantees can be upheld only as long as experts are identified as such, ${ }^{42}$ and are bypassed when the court unofficially uses experts who never appear on record, and when the parties disguise expert opinion in the formal pleading of counsel. ${ }^{43}$ It is for this reason precisely that the practice of using "expert counsel" was finally frowned upon in the Pulp Mills case, when the Court stated that it would have preferred to have them presented by the Parties as expert witnesses, "so that they may be submitted to questioning by the other party as well as by the Court". 4 This is undoubtedly a valid point, yet a court has little power to censor such a tactical practice, except by giving little evidential weight to the conclusions of such expert counsel (which the ICJ seems to have done in the case at hand). Paradoxically, while neither party used expert counsel in the Whaling case but rather presented properly appointed experts, the ICJ discarded their opinion as well - an attitude whose outcome will probably not encourage parties to use the suitable route. The same phenomenon thrives at the WTO but has drawn less attention and reprobation since there are no requirements regarding parties' delegations. The issue of their composition was indeed raised very early in the functioning of the dispute settlement system, via the specific question of whether independent private legal counsel could serve as a party's representative in addition to government officials. The Appellate Body held that Members are free to determine the composition of their delegation in the proceedings, ${ }^{45}$ and it is therefore not uncommon to have experts included in parties' delegations, as well as in the delegations of third parties who can also submit expert evidence to the panel. However, it must be noted that all the submitted reports are communicated to the parties, who (in principle) can comment on

42 And even such proper appointment might not always guarantee due process: in the Gulf of Maine case for instance, the parties were not invited to exercise their right to comment on the report of the court-appointed experts, see Rosenne, supra note 4, 1329.

43 See for instance Kasikili/Sedudu Island (Botswana/Namibia), Judgment, ICJ Reports (1999), 1045; Gabčikovo-Nagymaros Project (Hungary/Slovakia), Judgment, ICJ Reports (1997), 7.

44 Pulp Mills on the River Uruguay, supra note 2, para. 167.

45 Appellate Body Report, EC - Bananas III, Doc. WT/DS27/AB/R (adopted 09 September 1997), para. 10: "we can find nothing in the Marrakesh Agreement Establishing the World Trade Organization [...], the DSU or the Working Procedures, nor in customary international law or the prevailing practice of international tribunals, which prevents a WTO Member from determining the composition of its delegation in Appellate Body proceedings”. 
them and address any issues during the substantive meetings with the panel.

However, the issue of due process rights in WTO proceedings has appeared from a different and unprecedented angle in the Clove Cigarettes dispute. The decision indeed showed that the panel had strongly relied on a report made to the US Food and Drug Administration which it had not requested, nor which had been submitted by the parties as evidence (as it had not been made public at the time of submission). In other words, the panel had extended its fact-finding mission autonomously - although not spontaneously, since the report was mentioned in both parties' submissions. While this is not objectionable as such, given the extensive investigative powers of panels under Article 13, the panel in this specific case must nevertheless have been aware of its unusual initiative: it had indeed taken the precaution to address questions to the parties, inviting them to comment on specific substantial aspects of the report, on its relevance to the dispute, and on its utilisation by the panel. ${ }^{46}$ Interestingly, it steered clear of directly asking the parties whether they agreed or objected to its using the report, but rather asked whether they thought the panel "could conduct an 'objective assessment' of the matter before it under Article 11 of the DSU without" using it. The formulation in itself is curious, as it is the responsibility of the panel to apply the proper standard of review, which should not be dictated or even guided by the parties; one can assume, therefore, that the phrasing of the question was not left to chance and that it constituted an elegant way for the panel of avoiding to unequivocally ask the parties whether they agreed to its using the report. Even more interestingly, while both the defendant and the complainant declared that the panel could properly carry out its task without using it, ${ }^{47}$ the panel nevertheless considered that it "may rely on the [report] for the purpose of corroborating [its] findings, as this would be consistent with Articles 11 and 13 of the

46 The panel asked the following questions: “(i) whether the above mentioned recommendation contained in the March 2011 TPSAC Report was relevant to the dispute; (ii) what was the relevance of the March 2011 TPSAC Report to the question of whether menthol- flavoured cigarettes are 'like' clove cigarettes; (iii) to comment on the significance of the evidence presented by the March 2011 TPSAC Report concerning the rate of menthol cigarettes smoked by youth, in relation to the dispute; and (iv) whether the Panel could conduct an 'objective assessment' of the matter before it under Article 11 of the DSU without taking into consideration the March 2011 TPSAC Report”, see Panel Report, Clove Cigarettes, Doc. WT/DS406/R (adopted 02 September 2011), para. 7.223 note 449.

47 The complainant even stated that it was "not particularly relevant", ibid., para. 7.223 note 449 . 
DSU".48 The reference to Article 13 indicates that the panel considered the report to fall into the category either of "information from any relevant source" or of expert opinion - and yet its content was not and could not be discussed by the parties as regular evidence would have been: the second and last meeting with the parties was held on 15 February 2011, but the report was delivered to the FDA and made public only in March 2011.

\section{The exercise of the power to seek expert advice}

The previous section has established that the ICJ and WTO panels are similarly empowered to appoint experts, but most revealing is how both actually use these powers - or don't. Unsurprisingly, the exercise of their investigative powers remains in principle at their utter discretion (A). It is therefore all the more striking that WTO panels, in certain circumstances, are legally bound to seek expert advice (B). Furthermore, the standard of review imposed on panels strongly suggests that seeking expert advice, in certain circumstances, constitutes an integral requirement of the judicial function $(\mathrm{C})$.

\section{A. Discretionary recourse to experts}

Both the ICJ and WTO panels enjoy a wide margin of appreciation regarding the request for expert assistance. This discretion seems widest for the ICJ, given that Article 50 doesn't require that a case raise particular scientific or technical issues, as does Article 13 para. 2 DSU for the establishment of an Expert Review Group. ${ }^{49}$ This slight restriction set aside, and while it is true that the proceedings are mainly driven by an adversarial dynamic in which the parties have the primary responsibility to adduce the evidence and to bring a prima facie case, both the ICJ and WTO panels enjoy extensive authority to carry out and to control the process of establishing the relevant facts. ${ }^{50}$ As established in the previous section, their respective statute clearly "enables [them] to seek information and advice as they deem appro-

48 Ibid., para. 7.228.

49 This possibility is made available only "with respect to a factual issue concerning a scientific or other technical matter raised by a party to a dispute".

50 See for instance Appellate Body Report, US - Shrimp, Doc. WT/DS58/AB/R (adopted 12 October 1998), para. 106. 
priate in a particular case", ${ }^{51}$ regardless of whether the parties feel that expert consultation is not necessary or even disagree with the panel's decision to seek advice. ${ }^{52}$ However, a discretionary power can be exercised positively or negatively, and what is "deem[ed] appropriate" can be greatly at odds with what is necessary or even required. Regarding positive exercise of this discretion, the divide between ICJ and panel practice is gaping (1). But this factual observation alone does not allow for conclusions to be hastily drawn: when one also looks at the negative exercise of their discretionary power, i.e., at the absence of expert consultation, the difference between ICJ and WTO panels' practice becomes less clear-cut (2). Both courts indeed seem to have developed similar if not identical avoidance strategies, by which they bypass official expert appointment, which sheds a different light on the harsh criticism the ICJ is under, and on the comparative appraisal of the WTO dispute settlement.

\section{Positive exercise of discretionary power: addressing the need for expert advice}

The positive practice of WTO panels requires no lengthy demonstration, since the case law obviously demonstrates frequent expert consultation, to the point even that it may seem trivialized. The essential assistance provided by experts to the task of the judicial body was in fact acknowledged very early in the functioning of the dispute settlement mechanism, ${ }^{53}$ and panels have repeatedly stressed the "valuable" input provided by experts in order

51 Appellate Body Report, EC - Hormones, supra note 25, para. 147 [emphasis added].

52 See for instance the Panel Reports in US - Continued Suspension, supra note 13, para. 7.56; Canada - Continued Suspension, supra note 13, para. 7.54; US - Animals, Doc. WT/DS447/R (adopted 24 July 2015), para. 1.13; and Russia - Pigs (EU), supra note 10, para. 1.18. In all instances at least one party stressed that it did not see the need for the panel to request expert advice (although in the US/ Canada - Continued Suspension cases the EU than changed its stance and requested the establishment of an ERG, but failed to obtain it from the panel).

53 See for instance Appellate Body Report, India - Quantitative Restrictions, supra note 29, para. 142: expert opinion can be "useful in order to determine whether a prima facie case has been made" by the plaintiff. However, a panel oversteps its duty when it seeks expert advice to help it understand the evidence submitted by the parties, but then uses this evidence to find an inconsistency although the complainant has not established a prima facie case (see Appellate Body Report, Argentina - Textiles, Doc. WT/DS56/AB/R (adopted 27 March 1998), paras. 124-131). In other words, expert opinion can in no way be used as a substitute for a party's failure to meet the burden of proof. 
to understand the factual situation. ${ }^{54}$ Although it is difficult to give precise statistics of the cases in which panels have used experts, ${ }^{55}$ the nature of experts themselves being variable, it is nevertheless unquestionable that panels often seek expert opinion in disputes involving complex facts of a technical or scientific nature, and that they do not hesitate to consult with specialized international institutions such as the Codex Alimentarius Commission, the IMF or the WIPO. ${ }^{56}$ The attitude of the ICJ stands in striking contrast to this practice, as it has notoriously appointed experts in three disputes only (PCIJ included), the most recent of which already lies more than thirty years in the past. However, the Gulf of Maine case must be set apart, as it did not reflect a discretionary exercise of the Court's power: the Chamber of the Court, constituted according to the wishes of the parties, was in fact bound by the special agreement between Canada and the United States to appoint an expert (Article II (3)). ${ }^{57}$

In the other two disputes, the Chorzów Factory case and the Corfu Channel case, the Court spontaneously decided to appoint experts under Article 50 of its Statute. In Chorzów Factory, where its task was to determine the sum to be awarded to Germany in reparation for the dispossession of two companies by the Polish government, it explained its decision by the fact "that it cannot be satisfied with the data for assessment supplied by the Parties" ${ }^{58}$ Therefore, "in order to obtain further enlightenment in the matter", it decided to "arrange for the holding of an expert enquiry", 59 the main purpose of which was to determine the monetary value of the property at the time of dispossession as well as any profit that would have been made

54 E.g. Panel Report, Russia - Pigs (EU), supra note 10, para. 7.953.

55 But see the inventory of cases in Marceau, Hawkins, supra note 15, 494-495 notes $9,10$.

56 See for instance the aforementioned US/Canada - Continued Suspension cases, where the panel decided not only to consult individual experts but also sought information from the Codex Alimentarius Commission, the Joint FAO/WHO Expert Committee on Food Additives, and the International Agency for Research on Cancer (Panel Reports, supra note 13, respectively paras. 7.78, 7.76).

57 Delimitation of the Maritime Boundary in the Gulf of Maine Area (Canada v. United States of America), Judgment, ICJ Reports (1984), 253. The Court obliged by an order appointing Commander Peter Bryan Beazley, who was to "assist the Chamber in respect of technical matters and, in particular, in preparing the description of the maritime boundary and the charts referred to" in the compromise, see Delimitation of the Maritime Boundary in the Gulf of Maine Area (Canada v. United States of America), Order, ICJ Reports (1984), 166.

58 Factory At Chorzów (Merits) (Germany v. Poland), Judgment No 13 (1928), PCIJ Series A No. 17 (September 13, 1928), 49.

59 Ibid., p. 51. 
between that time and the time of the expertise. ${ }^{60}$ In Corfu Channel, the Court had to decide whether Albania could be held responsible for the damage suffered by the United Kingdom when two vessels of its fleet hit mines while passing through the channel, the existence of a breach by Albania of its international obligations depending essentially on whether or not it had knowledge of the minelaying activities in its territorial waters. As this called quite simply for an on-site experiment, the Court therefore appointed a committee of three experts, which was instructed to "examine the situation in the North Corfu Strait immediately before October 22 ${ }^{\text {nd }}$, 1946 , from the point of view of [...] the position of the swept channel $\left[\ldots . .{ }^{\prime \prime} 61\right.$

In the same case again, regarding the calculation of the amount of compensation due, the Court once more decided to seek expert advice, as the issue "involved questions of a technical nature". ${ }^{2}$ The experts' mandate was to "examine the figures and estimates stated in the last submissions filed by the Government of the United Kingdom regarding the amount of its claim for the loss of the Saumarez and the damage caused to the Volage." 63

Ultimately the reasons for appointing experts in both cases seem quite ordinary and commonsensical: dissatisfaction with the evidence submitted by the parties, and necessity to make a factual on-site verification. That experts should be appointed in such circumstances comes as no surprise, and

60 Factory At Chorzów (Merits), Order, PCIJ 2. I A. and B. (1928).

61 Corfu Channel (Merits), supra note 14, 124 (I. (1)). More specifically, the experts were requested to "ascertain whether it is possible [...] to draw any conclusions, and, if so, what conclusions, in regard to: (1) the means employed for laying the minefield discovered on November $13^{\text {th }}, 1946$, and (2) the possibility of mooring those mines with those means without the Albanian authorities being aware of it, having regard to the extent of the measures of vigilance existing in the Saranda region" (Ibid., p. 126 (I. (8)). Experiments on the spot were thus carried out, including a test of visibility by night, after which the experts concluded that it was "indisputable" that the minelaying operations must have been noticed by the coastguards (Corfu Channel (Merits), Judgment, supra note 14, 21). The Court, giving "great weight to the opinion of the Experts", therefore concluded that the minefields could not have been laid without the knowledge of the government (Ibid., 21-22).

62 Corfu Channel (Compensation), supra note 14, 247.

63 Corfu Channel (Compensation), Order, ICJ Reports 1949, 238 (1). The Court took due note of the figures produced by the experts, which were roughly the same as the sums claimed by the government of the United Kingdom. For the destroyer Volage, the UK had even claimed a sum slightly inferior to that estimated by the experts, but the Court could not go beyond the amount claimed by the government (Corfu Channel (Compensation), Judgment, supra note 14, 249). 
on the contrary it is most curious that the Court seems to have encountered no other such case of unconvincing evidence or need for clarification in almost a century of activity. Claiming otherwise simply lacks plausibility, given the growing factual complexity of certain cases over the last few decades, which allows for one conclusion only: while the need for expert consultation probably appears in many a case, the Court, using its discretionary power, simply avoids confronting that need, at least with the tools provided by its Statute.

\section{Negative exercise of discretionary power: circumventing the need for ex curia experts}

So far it has simply been confirmed that the practice of both courts could not be more different when one looks only at the positive request for expert advice. And yet, this comparison becomes unsteady upon closer examination of the instances in which experts are not called upon. Arguably, this is merely the other facet of any discretionary power, and is as such indisputable; the Appellate Body has even made sure to emphasize that "a panel is not duty-bound to seek information in each and every case or to consult particular experts under this provision. [...] Just as a panel has the discretion to determine how to seek expert advice, so also does a panel have the discretion to determine whether to seek information or expert advice at all." 64

However, this "negative" exercise of both courts' discretionary power is much more intriguing from a comparative perspective, as it reveals that WTO adjudicating bodies are no more virtuous than the ICJ: both in fact have a strong tendency to circumvent the tools explicitly provided for by their statutes, and to explore alternative avenues in order to deal with complex or technical issues; that this tendency thrives in the WTO system as well is merely obscured by the abundant evidence of ex curia experts' presence in the proceedings. Admittedly, this attitude of avoidance is less easy to prove since, by definition, it lacks positive and unequivocal evidence. Several tendencies can nonetheless be identified.

The easiest to spot is the explicit statement by the adjudicating body that further evidence is not required or that expert opinion would be use-

64 Appellate Body Report, Argentina - Textiles, supra note 53, para. 84; Appellate Body Report, US - Shrimp, supra note 50, para. 104. 
less, ${ }^{65}$ which becomes all the more intriguing when the Court or the panel later concludes that the claim is not substantiated or that the evidence presented was unconvincing. This is particularly striking in contrast to the attitude displayed in Chorzów Factory where, for the first and until now only time in PCIJ/ICJ history, the Court explained its decision to appoint experts by the insufficiency of the evidence provided by the parties. In a similar vein, the Court also seems to have circumvented the possible need for expert advice by "neutralizing" the technical or scientific issue at stake. This appears most distinctly in certain boundary disputes in which technical matters are simply deflected; ${ }^{66}$ as well as in Gabč́kovo-Nagymaros where the ICJ, after stating that it had "given most careful attention" to the abundant material presented by the parties, considered that "it is not necessary in order to respond to the questions put to it in the Special Agreement for it to determine which of those points of view is scientifically better founded".67 Other cases reveal a blunter approach, which consists of the Court ignoring outright the very existence of a scientific or technical difficulty that calls for expert assistance, and to undertake to address, assess and resolve the issue by its own means. It is this attitude that has provoked the harshest

65 In the Nicaragua case for instance, the Court admitted that one of its "chief difficulties" had been the determination of the relevant facts and emphasized that it was obliged "to employ whatever means and resources may enable it to satisfy itself whether the submissions of the applicant State are well-founded in fact and law, and simultaneously to safeguard the essential principles of the sound administration of justice"; yet it felt it was "unlikely" that an enquiry by a court-appointed expert body "would be practical or desirable" (Military and Paramilitary Activities in and against Nicaragua (Merits) (Nicaragua v. United States of America), Judgment, ICJ Reports 1986, paras. 57, 59, 62). Admittedly, the undertaking might indeed have proven difficult considering the refusal of the United States to even appear before the ICJ, but it is interesting that the Court chose to openly discuss its exercise of the power to appoint experts precisely in a dispute whose circumstances where such that no reasonable criticism could be voiced for its decision not to consult experts. But see also dissenting opinion of.

66 See for instance the Maritime Delimitation case between Qatar and Bahrain where the ICJ dismissed the issue of the exact nature of Fasht al Azm (is it part of the island of Sitrah or a low-tide elevation?); regarding the island of Qit'at Jaradah, without much discussion it applied its previous jurisprudence of eliminating the disproportionate effect of small islands (Maritime Delimitation and Territorial Questions between Qatar and Bahrain (Merits) (Qatar v. Bahrain) Judgment, ICJ Reports 2001, paras. 218, 219). See also Continental Shelf (Tunisia/Libyan Arab Jamahiriya), Judgment, ICJ Reports 1982, paras. 61, 67. See also Continental Shelf (Libyan Arab Jamahiriya v. Malta), Judgment, ICJ Reports 1985, para. 64.

67 Gabčikovo-Nagymaros Project, supra note 43, para. 54. 
criticism, particularly in boundary ${ }^{68}$ and environmental disputes, notably the Pulp Mills case. ${ }^{69}$ Judges Al-Khasawneh and Simma denounced this approach as being "methodologically flawed", to the extent that the issues were of a nature "which the Court cannot, as a court of justice, fully comprehend without recourse to expert assessment" ${ }^{70}$ and they consequently questioned the entire conclusions reached by the Court. Judge Yusuf was similarly critical, concluding that "there is reason for concern" when even a case of such complexity does not compel the Court to use its power under Article $50 .{ }^{71}$ However, in the Whaling case the Court again did not feel it was appropriate, let alone required, to appoint an independent expert and thus proceeded on its own to assess whether the Japanese whaling programme was covered by the exception provided for in the International Convention for the Regulation of Whaling, according to which permits can be delivered for whaling conducted "for purposes of scientific research".

Arguably, no such reproach can be made in relation to WTO panels but for reasons explained below and that cannot be reduced to a more expert-friendly disposition. And yet, contrary to all appearances, WTO dispute settlement nurtures exactly the same tendency of avoiding official expert consultation as the ICJ, by using what is commonly called "ghost experts" (experts fantômes). Regarding the ICJ this practice was notoriously made public by none other than its former president Sir Robert Jennings, according to whom "the Court has not infrequently employed cartographers, hydrographers, geographers, linguists, and even specialized legal experts to assist in the understanding of the issue in a case before it; and it

68 See for example the boundary dispute between Namibia and Botswana where the Court, presumably without specific knowledge in hydrology, decided by itself which of the two channels was the "main" one merely based on three sets of documents: Kasikili/Sedudu Island, supra note 43, para. 80 .

69 The Court had to decide whether Uruguay had breached its obligation to prevent pollution and to preserve the environment, and both parties had submitted an impressive amount of scientific material and expert studies, as well as presented their own experts. While every single conclusion was strongly disputed between the parties and the experts, the Court nevertheless declared that it would "keep $[\ldots]$ with its practice" and thus "make its own determination of the facts, on the basis of the evidence presented to it", Pulp Mills on the River Uruguay, supra note 2, para. 168.

70 Pulp Mills on the River Uruguay, joint dissenting opinion of Judges Al-Khasawneh and Simma, supra note 4, paras. 2, 5.

71 Pulp Mills on the River Uruguay, declaration of Judge Yusuf, ICJ Reports 2010, 216, para. 13. 
has not on the whole felt any need to make this public knowledge or even to apprise the parties" 72

No equally reliable testimony has been made about the WTO dispute settlement system, but there is valid reason to suspect that the same phenomenon thrives in WTO proceedings. To a certain extent one could argue that this practice is even covered by the statute: according to Article 27 para. 1 DSU, indeed, "the Secretariat shall have the responsibility to assist panels, especially on the legal, historical and procedural aspects of matters dealt with, and of providing secretarial and technical support".

Evidently the DSU thus makes room for the Secretariat in the adjudicative process, and not only regarding technical issues: Article 27 explicitly covers legal matters, the very core of the judicial function and it is well known that the Secretariat staffs support teams to panellists with lawyers.

In addition, what is exactly meant by "technical support" is conveniently ambiguous and authors have suggested different interpretations, which inflate or inversely deflate the Secretariat's powers in the adjudicative process. The most minimalistic reading would reduce such "technical support" to purely administrative matters, ${ }^{73}$ whereas a more liberal approach includes economic expertise. ${ }^{74}$

However, considering that the Secretariat's role is explicitly acknowledged by the DSU, in the same manner as expert consultation under Article 13 , it can only seem odd that no panel decision has ever recorded or even mentioned information provided by the Secretariat. The discrepancy between, on the one side, the transparency policy regarding expert consultation, other international organizations or amici curiae and, on the other side, the absence of any reference to Secretariat assistance thus inevitably raises questions about the extent and value of the assistance provided by the Secretariat, whose actual role in the proceedings remains concealed in the uncertainty provided by silence. ${ }^{75}$

72 Sir R. Y. Jennings, International Lawyers and the Progressive Development of International Law, in J. Makarczyk (ed.), Theory of International Law at the Threshold of the 21st Century - Essays in Honour of Krzystof Skubiszewski (1997), 416.

73 See C. A. Thomas, Of Facts and Phantoms: Economics, Epistemic Legitimacy, and WTO Dispute Settlement, 14 JIEL (2011), 317.

74 C. P. Bown, The WTO Secretariat and the Role of Economics in DSU Panels and Arbitrations, in C. P. Bown, J. Pauwelyn (eds.), The Law, Economics and Politics of Trade Retaliation in WTO Dispute Settlement (2010), 391.

75 For lack of accessible information there are few studies of the role of the Secretariat, but see H. Nordström, The WTO Secretariat, 39(5) Journal of World Trade (2005), 819; and Bown, supra note 74 . 
This, in turn, raises procedural and systemic issues. On the one hand, it is true that Article 13 enables panels to "seek information and technical advice from any individual or body it deems appropriate" (Article 13 para. 1, emphasis added) and, more generally, "from any relevant source" (Article 13 para. 2), which leaves room for a broad interpretation. On the other hand, such request for information from outside sources can certainly not be construed so liberally as to allow for an opaque process in which WTO bodies exterior to the adjudicators could staff assistance teams with lawyers and other specialists, and for the panel to use thereby obtained information or knowledge by presenting it as its own. And yet there is ample indirect evidence that lawyers and economists significantly assist the adjudicators. Trade remedy disputes and Article 22 para. 6 arbitral awards on the assessment of damages and the amount of equivalent retaliation make abundantly clear that the calculations are unlikely to be the doing of the panellists and arbitrators alone, and that "outside" bodies are staffing economic (and presumably also legal) support teams to the adjudicating bodies. ${ }^{76}$ This further raises many questions: are the consulted economists not "experts" in the sense of Article 13 para. 2 DSU? If so, why are they not appointed as such, and their opinion and advice not subjected to the observations of the parties? If not, where do they come from? If they are provided by the Secretariat, ${ }^{77}$ arguably their assistance could fall under Article 27 DSU. But the WTO has various divisions, among others a Legal Affairs Division, a Rules Division, and an Economics Research and Statistics Division that could equally provide such economists ${ }^{78}$, in which case the lines drawn by the DSU clearly become blurred, and the adjudicating body - officially the panel or the arbitrator - becomes an indistinct organ of unknown composition. The "in-house expertise" provided by economists (and lawyers) to panels is not prohibited per se, but it is certainly objectionable that this practice operates without any transparency, and completely

76 See on this matter the detailed study of C. P. Bown, ibid.

77 As reported by Marceau, Hawkins, supra note 15, 504.

78 The practice is suggested both by P. Mavroidis and J. Pauwelyn, see P. C. Mavroidis, 'Let's Stick Together (and break with the Past)' (2005) Columbia University Academic Commons (available at https://doi.org/10.7916/D8ZK5PCP);

J Pauwelyn, The Use, Non-Use and Abuse of Economics in WTO and Investment Litigation, in J. A. Huerta-Goldman et al., WTO Litigation, Investment Arbitration, and Commercial Arbitration, Kluwer (2013). According to C. Bown as well, the support teams at the panel stage have rarely been staffed with economists provided by the Secretariat. 
outside the procedural constraints intended to safeguard the parties' due process rights.

Arguably there is thus little difference between the implication of unidentified economists in panel or arbitral proceedings and the cartographers, hydrographers, geographers, etc. purportedly consulted by the ICJ. Quantitatively, one can even assume that this habit is much more abundant and developed in WTO dispute settlement, considering the number of cases adjudicated and their inherent factual complexity and technical nature. Ghost experts, however convenient they may be for a court and however valuable the input they provide, present a systemic issue to the adjudicative process and the sound administration of justice, and the WTO dispute settlement system evidently calls for no less criticism in this regard and raises no fewer questions than with the ICJ.

\section{B. Mandatory recourse to experts}

In addition, drawing a comparison between the practice of WTO panels and the ICJ regarding ex curia experts appears to be based on the assumption that both courts enjoy the same discretion in deciding if and when to request assistance. This is not so. While it is true that, in principle, they have a discretionary authority in the matter, WTO dispute settlement has the remarkable feature of providing for mandatory recourse to experts: the SPS Agreement indeed obliges panels to seek expert opinion. ${ }^{79}$ Article 11 para. 2 thus provides that:

In a dispute under this Agreement involving scientific or technical issues, a panel should seek advice from experts chosen by the panel in consultation with the parties to the dispute. To this end, the panel may, when it deems it appropriate, establish an advisory technical experts group, or consult the relevant international organizations, at the request of either party to the dispute or on its own initiative (emphasis added).

This formulation calls for two observations. Firstly, panels are under an explicit obligation to seek expert advice in one circumstance: when the dispute involves "scientific or technical issues". Secondly, one of the means by which the panel can satisfy this requirement is by establishing an expert

79 Arguably one could add Article XV para. 2 of the GATT regarding IMF consultation, but as pointed out before the provision does not address panels as such, although it would undoubtedly apply to them. 
group, but this remains discretionary: the only obligation is that the panel seeks expert advice, but whether it obliges by appointing or consulting individuals or an expert group is left to its discretion ${ }^{80}$.

This obligation is strikingly at odds with the discretionary authority to seek expert advice and is therefore remarkable in itself, but its significance in relation to the ICJ must be put into perspective. As noted before, many commentators have indeed referred to the positive practice of WTO adjudicators in comparison to the ICJ's reluctance to appoint experts. To be fair, however, the number of cases in which WTO panels have requested assistance seems to have little to do with a more favourable inclination towards expert advice. Quite simply, in a great number of the recorded cases in which experts were consulted, panels have sought their advice because they had a legal duty to do so. ${ }^{81}$ Arguably indeed, any SPS dispute potentially involves "scientific or technical issues", as they touch on protective domestic measures that need to be based on "scientific principles" and "scientific evidence" (Article 2 para. 2 SPS Agreement), thus requiring a risk assessment. Such risk assessment being scientific by nature, it is unlikely that a panel could make a valid argument that no "scientific or technical issue" was involved, thus dispensing it from consulting experts. Paradoxically, this argument is confirmed by the only case in which the panel seems to have consulted no expert at all, the US - Poultry (China) dispute. But what might seem an anomaly, considering the panel's legal obligation, is in fact explained by the circumstances of the case. The United States had in fact presented no evidence at all to prove the existence of a risk assessment, nor any other specific scientific justification, and the panel could therefore do little more than conclude that such assessment did not exist, without having to evaluate how it was conducted and whether the US measure was based on it. ${ }^{82}$ Thus, while the dispute certainly involved "scientific issues", the panel did not have to address them substantially and, consequently, expert assistance was not needed. But in disputes that call for a substantial assessment of the conformity of a Member's conduct with WTO rules, the Appellate Body has stressed that "a panel may and should rely on the advice

80 This is confirmed by the Appellate Body in EC - Hormones, supra note 25, para. 147.

81 This is true in particular with respect to the cases cited by Judges Al-Khasawneh and Simma in their joint dissenting opinion in the Pulp Mills case, supra note 4, para. 16.

82 Panel Report, US - Poultry (China), Doc. WT/DS392/R (adopted 29 September 2010), paras. 7.175-7.204. 
of experts in reviewing a WTO Member's SPS measure, in accordance with Article 11.2 of the SPS Agreement and Article 13.1 of the DSU" 83

\section{Seeking expert advice as a requirement of the judicial function?}

In addition to explicitly obliging panels to seek expert advice in SPS disputes, another distinctive feature of WTO dispute settlement is to constrain a panel's exercise of its margin of appreciation by imposing a specific standard of review. Indeed, contrary to the ICJ whose discretion is absolute and, in any event, not subject to review, the function of WTO panels is fundamentally framed by Article 11 DSU, which requires them to make "an objective assessment of the matter before [them], including an objective assessment of the facts of the case and the applicability of and conformity with the relevant covered agreements" (emphasis added).

The Appellate Body's previously quoted statement according to which a panel's authority under Article 13 includes the authority to decide not to seek any information or expert advice at all must therefore be nuanced by a crucial constraint, made apparent in the US - Shrimp case: the panel's authority under Article 13 "is indispensably necessary to enable a panel to discharge its duty imposed by Article 11 of the DSU to 'make an objective assessment of the matter before it, including an objective assessment of the facts of the case and the applicability of and conformity with the relevant covered agreements [...]"”. ${ }^{84}$

Whilst this statement can be read positively, in the sense that it justifies the panel's wide authority in exercising its investigative powers, it can also be reversed, in the sense that it puts a considerable strain on the panel. Article 11 DSU indeed creates a strong tension between the panel's discretion regarding the process of determining the facts on the one hand, and its duty to conduct an "objective assessment of the matter" on the other. The point of balance is to be found in the manner in which a panel actually exercises its authority, and which will vary from one case to another. In other words, the incorrect exercise of a panel's discretion can in itself constitute a violation of its judicial function as tailored by Article 11.

At the same time, the standard of review enshrined in Article 11 DSU must be properly framed and defined: how much autonomous "investiga-

83 Appellate Body Report, US/Canada - Continued Suspension, supra note 38, para. 592 [emphasis added].

84 Appellate Body Report, US - Shrimp, supra note 50, para. 106 [emphasis added]. 
tive" initiative can and should be expected of a panel? This is a particularly sensitive issue in WTO dispute settlement, where many a case is brought before the adjudicating bodies after national authorities have already made determinations of the factual situation (for instance risk assessment in SPS disputes, or determinations regarding the existence of a dumping practice or subsidies). This issue was clarified as early as the EC-Hormones case, where the Appellate Body held that "the applicable standard [of review] is neither de novo review as such, nor 'total deference,' but the 'objective assessment of facts"”. 85

In other words, panels are prohibited from entirely substituting their own factual investigation and determinations to the evidence presented by the parties, but they are equally prohibited from uncritically relying on factual determinations made by the parties without probing and questioning their conformity with the standards laid out in the WTO agreements. The threshold thus drawn evidently touches upon the issue of whether or not expert consultation is required: panels, as the triers of the facts, are obliged by Article 11 to make use of their authority in such a manner that they are able to meet the required standard of review. This in turn implies that the positive exercise by a panel of its authority under Article 13, by seeking expert advice, may be "indispensably necessary" to an objective assessment of the matter. ${ }^{86}$ As we will see later, the Appellate Body does not lightly reach the conclusion that there has been a failure by the panel to conduct an objective assessment. However, several disputes have remarkably brought to light that the panels' discretion to request expert advice can in fact be constrained to the point of vanishing: the standard of review constitutes a mobile cursor which, depending on the circumstances of a case, can require panels to exercise their authority in one manner only, by positively deciding to seek expert assistance.

The first dispute to address the issue was Argentina - Textiles, in which Argentina argued that the panel had failed to make an "objective assessment of the matter" by not acceding to the request of the parties to consult with the IMF. The Appellate Body started by noting that a panel is not legally bound by Article 13 para. 2 to consult experts and that it rather enjoys discretionary authority in the matter; consequently, a panel has the

85 Appellate Body Report, EC - Hormones, supra note 25, par. 117.

86 Appellate Body Reports, US - Shrimp, supra note 50, paras. 104 and 106; Japan Agricultural Products II, supra note 14, para. 127. See also Appellate Body Reports in Canada - Aircraft, WT/DS70/AB/R, 2 August 1999, para. 192; and US Continued Zeroing, Doc. WT/DS350/AB/R (adopted 04 February 2009), para. 347. 
discretion to decide not to seek expert advice, and in the present case the Appellate Body found no inconsistency with the duty to objectively assess the matter. ${ }^{87}$ It nonetheless expressed mild criticism of the panel's decision, by emphasizing that "it might perhaps have been useful" to consult with the IMF. ${ }^{88}$

A more stringent position was taken in the US - Large Civil Aircraft dispute, where the European Union claimed that the panel had failed to objectively assess the matter and thus infringed on the EU's due process rights by finding there was insufficient evidence to make a determination on one of the US programmes under review. More specifically, the EU contested the refusal of the panel to seek out factual information from the United States that would have enabled it to make the disputed determination. The Appellate Body agreed with the EU, and pointed out that when indispensable information is in the exclusive possession of another party, the panel would be unable to make an objective assessment of the matter unless it positively exercises its authority by actively seeking out that information. ${ }^{89}$ In the present case the EU had sought to obtain the information from the US, met persistent refusal and had thus requested the panel to seek it out instead. The panel's refusal was criticised by the Appellate Body, who considered that this was the "only way" to allow for an objective assessment of the claim, and that the particular circumstances of the dispute "demanded that the Panel assume an active role in pursuing a train of inquiry". ${ }^{\circ}$ Failing to seek the necessary information amounted to compromising the panel's ability to make an objective assessment, and thus constituted a violation of its obligation under Article 11. ${ }^{91}$

This decision demonstrates that the conclusion of "insufficient evidence" that a judicial body may be inclined to draw must be handled with great care, at least when it can be subjected to appellate review. It further shows that, even when the proceedings are primarily driven by the parties, the adjudicating body may be duty-bound to exercise all authority required in order to correctly carry out its judicial function. While the present decision dealt with the general power to seek out information, there is no reason why the Appellate Body's findings should not equally apply to expert consultation under Article 13 para. 2, when such consultation proves nec-

87 Appellate Body Report, Argentina - Textiles, supra note 53, paras. 84-86.

88 Ibid., para. 86.

89 Appellate Body Report, US - Large Civil Aircraft (2 ${ }^{\text {nd }}$ Complaint), Doc. WT/ DS353/AB/R (adopted 12 March 2012), para. 1129.

90 Ibid., paras. 1143-1144 [emphasis added].

91 Ibid., paras. 1144-1145. 
essary in order to enable the panel to accomplish its task. In other words, not requesting expert opinion can in itself constitute a wrongdoing, and the Appellate Body has shown its readiness to severely review the exercise of a panel's authority.

But this approach of the adjudicator's standard of review, however remarkable with regard to the obligation of seeking expert advice that can be derived from it, is obviously not transposable as such to the ICJ, since the Court remains solely responsible for "tailoring" its standard of review. As the Whaling case has revealed, this can lead to what Judge Bennouna has called an "impressionistic" line of reasoning, ${ }^{92}$ in which the Court, unconstrained in the exercise of its authority, can admit that it is not in a position to determine whether a programme constitutes "scientific research", decline the definition proposed by the party-appointed experts and yet not appoint independent ones, then go on to identify a standard of review that is nowhere to be found in the treaty under examination, and ultimately, on the basis of a misplaced standard of review, confront a treaty provision whose meaning has not been clarified with the facts of the case. This approach has been widely criticized, including from the bench ${ }^{93}$ and again with reference to the WTO dispute settlement system and its standard of review, but the fact remains that the ICJ cannot be held to the standards imposed on WTO panels.

\section{The utilisation of expert evidence}

The last matter to be dealt with in a comparative perspective is how expert opinion is used by the ICJ and WTO panels. But once more, the attempted comparison soon reaches its limit of relevance, as the WTO agreements put constraints on the panels of which the ICJ is unburdened. This appears both in respect to the legal authority of expert evidence (A) and its assessment by the adjudicating bodies (B).

92 Whaling in the Antarctic, supra note 3, 341, Dissenting opinion of Judge Bennouna.

93 See Whaling in the Antarctic, supra note 3, dissenting opinions of Judges Owada, Abraham, Bennouna, and Yusuf; the separate opinions of Judges Xue, and Sebutinde; and the declaration of Judge Keith. 


\section{A. Authority of expert evidence}

Expert evidence is, intrinsically, no different from any other piece of evidence presented, and neither the ICJ nor WTO panels are therefore, in principle, bound to take it under consideration. Expert opinion is only advisory ${ }^{94}$ and, as for any piece of evidence submitted, the adjudicating body has the authority to accept and consider it or to reject it, or even "to make some other appropriate disposition thereof" ${ }^{95}$ The Appellate Body even emphasized that:

The fact that a panel may motu proprio have initiated the request for information does not, by itself, bind the panel to accept and consider the information which is actually submitted. ${ }^{96}$

At the same time, with regard to its substance and authority, it is hardly deniable that expert evidence is different from ordinary evidence, since it is provided by an individual or body with specialized knowledge in an area outside the judge's technical competence. This could explain why the WTO system has carved out several remarkable exceptions in which panels are legally bound by expert opinion; this incidentally draws a distinction between individual expertise which is advisory only and group expertise. ${ }^{97}$ The Agreement on Customs Valuation provides that panels "shall take into consideration the report of the Technical Committee" ${ }^{98}$ thereby expressing a minimal obligation in the sense that the panel is forbidden to simply ignore expert testimony and has to at least acknowledge the report. The SCM Agreement however takes a more incisive approach regarding the assistance of the Permanent Group of Experts in determining the existence of a prohibited subsidy. Recourse to the PGE may be a discretionary decision of the panel, but once its assistance has been requested the panel is bound: Article 4.5 indeed provides that the PGE's conclusions "shall be accepted by the panel without modification". A similar obligation weighs on the panel regarding consultation of the IMF by virtue of GATT Article XV para. 2, which provides that the determinations of the IMF regarding foreign exchange, monetary reserves and balances of payments shall be accepted. This unusual limitation of a court's discretion could explain why nei-

94 This is even made explicit in DSU Appendix 4, para. 6, which provides that "the final report of the expert review group shall be advisory only".

95 Appellate Body Report, US - Shrimp, supra note 50, para. 104.

96 Ibid., paras. 106, 108.

97 Truilhe-Marengo, supra note 1, 210.

98 Article 19 para. 4 SCM Agreement. 
ther the PGE for subsidies nor the Technical Committee on Customs Valuation have never, so far, been called upon by a panel. To the extent that their conclusions will predetermine the results of the panel's review, this type of group or institutional expertise may be felt as a severe encroachment on the judicial function, as it effectively neutralizes the panel's autonomy and constrains its essential role as trier of the facts.

\section{B. Assessment of expert evidence}

Regarding the weighing and assessment of expert evidence, the same profound differences between both systems appear behind the similar general principles. Neither the ICJ Statute and Rules nor the DSU contain detailed evidentiary rules and the adjudicating bodies thus enjoy a wide discretion. ${ }^{99}$ In the Nicaragua case the Court thus explicitly stated that:

[...] within the limits of its Statute and Rules, it has freedom in estimating the value of the various elements of evidence. ${ }^{100}$

However, it nevertheless seems to have become more attentive to the necessity of clarifying its treatment of the evidence, especially in factually complex disputes. This became apparent in the Armed Activities case, where it took the precaution of explaining its general methodology for assessing the weight, reliability, and value of the evidence submitted, ${ }^{101}$ and consequently undertook to "map" the different types of evidence and their respective probative value, depending on their content, their origin, their authenticity and their reliability. ${ }^{102}$ Particular care was again given to the evidential matters in the Genocide cases, where the Court for the first time explicitly distinguished and dealt with three sets of issues - burden, standard, and methods of proof ${ }^{103}$ - both cases confirming a categorisation of the evidence according to the degree of their probative value. This general

99 See in general D. Dwyer, The Judicial Assessment of Expert Evidence (2008).

100 Military and Paramilitary Activities in and against Nicaragua (Merits), supra note 65, para. 60.

101 Armed Activities on the Territory of the Congo (DRC v. Uganda), Judgment, ICJ Reports 2005, para. 59.

102 For instance ibid., para. 61.

103 Application of the Convention on the Prevention and Punishment of the Crime of Genocide (Bosnia and Herzegovina v. Serbia and Montenegro), supra note 8, 43, paras. 202-230; more apparent even in Application of the Convention on the Prevention and Punishment of the Crime of Genocide (Croatia v. Serbia), supra note 8, paras. 167-199 (“Questions of Proof”). 
methodology is also reflected in the treatment of expert evidence, where the case law reveals a different positioning of the Court depending on the origin and the content of the evidence. Thus it is not surprising that it is inclined to give great weight to the testimony of court-appointed experts, as they provide independent opinion, ${ }^{104}$ while it seems to take a much more cautious approach regarding the testimony of party-appointed experts (or expert counsel). ${ }^{105}$

WTO panels on the other hand do not enjoy the same extent or "quality" of discretion. It is true that the "determination of the credibility and weight properly to be ascribed to [...] a given piece of evidence is part and parcel of the fact finding process and is, in principle, left to the discretion of a panel as the trier of facts".106

It is also true that this discretion includes the freedom for the panel to significantly depart from the value that a party attaches to a given expert report or opinion, ${ }^{107}$ as well as to accord probative value to a scientific minority opinion. ${ }^{108}$ However, the similarity with the ICJ's discretion ends here, and with it the basis for comparing both courts' practice vanishes. The discretion of WTO panels in the evaluation of expert evidence is indeed not untrammelled, once again because of the panel's essential obligation to carry out an "objective assessment of the facts of the case". The standard of review enshrined in Article 11 DSU thereby provides an insurmountable frame for the manner in which panels can and should deal

104 See for instance Corfu Channel (Merits), supra note 14, 21, where the Court emphasized the "guarantee of correct and impartial information".

105 Regarding the latter, the Court appears to take a nuanced stance mainly based on the content of the expert opinion, and seems to be particularly attentive to evidence against a party's own interest. In the Nicaragua case, the Court thus considered the evidence of a party against its own interest to be of "superior credibility" (Military and Paramilitary Activities in and against Nicaragua (Merits), supra note 65, para. 64). Similarly, in the Whaling case the Court quoted the expert appointed by Japan, who had expressed criticism of Japan's lack of transparency regarding the activities conducted under JARPA II (Whaling in the Antarctic, supra note 3, para. 159).

106 Appellate Body Reports, EC - Hormones, supra note 25, para. 132; EC - Sardines, Doc. WT/DS231/AB/R (adopted 26 September 2002), para. 300; US Shrimp, supra note 50, para. 104. See also S. Andersen, Administration of Evidence in WTO Dispute Settlement Proceedings, in R. Yerxa, B Wilson (eds.), Key Issues in WTO Dispute Settlement (2005), 177.

107 See for instance Appellate Body Report, Japan - Apples, Doc. WT/DS245/AB/R (adopted 26 November 2003), paras. 232-238.

108 Appellate Body Report, US/Canada - Continued Suspension, supra note 38, paras. 591, 597. 
with expert evidence. To a certain extent, the case law has shown that the Appellate Body is not inclined to lightly blame the panel for violation of its duty under Article 11. In particular, it has stated most clearly that it does not intend to "second-guess" the panel in evaluating the probative value of the evidence submitted, ${ }^{109}$ and that the panel would have to disregard, refuse to consider, wilfully distort or misrepresent the evidence submitted in order to have failed its obligation to conduct an objective assessment. ${ }^{110}$ When the Appellate Body held that these attitudes imply an "egregious error that calls into question the good faith of a panel", 111 it became clear that this threshold is not intended to impose specific evidentiary rules on the panel, but more fundamentally to protect the parties' rights of due process. Consequently, even when the Appellate Body expresses criticism of the panel's reasoning it does not casually conclude that there has been a failure to objectively assess the facts. ${ }^{112}$

At the same time, the case law has also revealed that the standard of review can serve another crucial purpose, which is to safeguard the judicial function by establishing a clear-cut distinction between the mandate of the judicial body and the expert's mandate. The issue was already made apparent in the India - Quantitative Restrictions case, when the Appellate Body held that:

A panel may not delegate its judicial function to an international organization that it consults, but must instead critically assess the views of that international organization. ${ }^{113}$

In concrete terms this means that - with the exception of binding expert evidence - a panel may refer to expert opinion, it may even accord considerable weight to it, but its conclusions must nevertheless be based on its own examination and assessment of this evidence. Once more, this touches upon the point of balance enshrined in the standard of review, which was emphasized in the $E C-$ Hormones case when the Appellate Body rejected

109 Appellate Body Reports, Korea - Alcoholic Beverages, Doc. WT/DS75/AB/R (adopted 18 January 1999), para. 161; EC - Asbestos, Doc. WT/DS135/AB/R (adopted 12 March 2001), para. 177.

110 Appellate Body Report, EC - Hormones, supra note 25, para. 133.

111 Ibid.

112 See for instance Japan - Apples, supra note 107, paras. 227-229, where the Appellate Body felt that the panel "could have been clearer", but nevertheless found no inconsistency with article 11.

113 Appellate Body Report, India - Quantitative Restrictions, supra note 29, para. 149. For an analysis of the relation between panel and expert, and their respective roles, see also Ngambi, supra note 1, 328-330. 
both a de novo review and a deferential review. In other words, under no circumstance can a panel forsake its judicial function by blindly relying on expert evidence, nor can it exceed the inherent limits of this function by discarding expert evidence and substituting its own technical or scientific opinion. This constraint of the standard of review thus has two facets: on the one hand it protects the parties, as the judge can be censured for overstepping his mandate and interfering in matters outside the ambit of its function; on the other hand, it is also a crucial safeguard for the judge, as it asserts the different mandates of both court and experts, and subordinates the latter. Experts may provide their own analysis, they may even be tempted to blend in a legal qualification, but the standard of review should effectively prevent this expert assessment from invading the essential functions of a court of law such as the interpretation of legal terms and the qualification of the facts. ${ }^{114}$

The importance of an adequately defined and applied standard of review appears in crude light by comparing the Whaling case before the ICJ and the US/Canada - Continued Suspension case before the WTO. In the Whaling case, the ICJ considered that it was not necessary to define "scientific research" in the sense of the treaty but nevertheless ventured onto the unstable ground of deciding whether an activity is conducted "for the purposes of scientific research" (emphasis added), thus drawing a precarious distinction between "scientific research" and activities conducted "for the purposes" of scientific research. How the purpose of an activity can be determined when the allowed aim of such activity (scientific research) has not been defined is as such incomprehensible, but the Court nevertheless carried out this assessment by invoking a standard of review of "reasonableness". In a nutshell, according to this standard, a programme pursues purposes of scientific research if "the elements of [its] design and implementation are reasonable in relation to its stated scientific objectives".115 The Court furthermore considered that "this standard of review is an objective one", 116 which might be an unfortunate and misconstrued borrowing from the WTO dispute settlement and its standard of review of "objective assessment". ${ }^{117}$ This objective reasonableness in turn was to be assessed based on several elements, including the scale of lethal sampling and the

114 Regarding the ICJ, this point was stressed by Judges Al-Khasawneh and Simma in the Whaling case in their joint dissenting opinion, supra note 4, para. 12.

115 Whaling in the Antarctic, supra note 3, para. 88, see also ibid., para. 67.

116 Ibid., para. 67.

117 For a comparison with the WTO standard of review, see the dissenting opinion of Judge Owada in the Whaling case, supra note 3, para. 33. 
methodology used to select sample size. The bias is immediately apparent: the nature and purpose of a programme is not affected by the methods used, and it can be conducted for purposes of scientific research regardless of the objectionable character of the methods. The Court was not called upon to pass judgment on the quality of the programme, but solely to determine whether it was conducted for the purposes of scientific research. However, absent any assistance from independent experts and on the basis of a questionable standard of review of "objective reasonableness" that is neither explicit in the convention nor implied by it, the Court did exactly what Article 11 DSU prohibits for WTO panels: it assessed the scientific merits of the Japanese whaling programme, ultimately passing judgment on what constitutes best science in its own view. ${ }^{118}$ This line of reasoning demonstrates a confusion of functions, when the Court's mandate was exclusively limited to determining whether the special whaling permits were issued "for purposes of scientific research" within the meaning Article VIII of the convention.

In the US/Canada-Continued Suspension case before the WTO the panel took exactly the same excessively liberal approach to its function as did the ICJ in the Whaling case - but with the considerable difference that its review could be and was effectively censured on appeal. The Appellate Body made clear that the standard of review according to Article 11 DSU imposes objectivity on the panel and thus necessitates refrain from giving judgment on the scientific value of a domestic risk assessment:

The review power of a panel is not to determine whether the risk assessment undertaken by a WTO Member is correct, but rather to determine whether that risk assessment is supported by coherent reasoning and respectable scientific evidence and is, in this sense, objectively justifiable. ${ }^{119}$

118 For a critical assessment, see S. R. Tully, 'Objective Reasonableness' as a Standard for International Judicial Review, 6 J. Int. Disp. Settlement (2015), 546; Mbengue, International Courts, supra note 1, 73; T. Scovazzi, Between Law and Science: Some Considerations Inspired by the Whaling in the Antarctic Judgment, Questions of International Law (2015), 13; Lima, supra note 21; L. C. Lima, Weighing the Evidential Weight of Expert Opinion: The Whaling Case, Questions of International Law (2015), 31; Peat, supra note 1, 286-288; Moncel, supra note 17.

119 Appellate Body Report, US/Canada - Continued Suspension, supra note 38, para. 590 . 
The manner in which the panel deals with the evidence presented by experts equally comes under the purview of the Article 11 standard of review, ${ }^{120}$ as neither the panel nor the experts are called upon to appreciate the exactitude of the risk assessment carried out by a Member. ${ }^{121}$ Furthermore, the panel cannot probe the experts in order to determine whether they would have conducted the risk assessment differently or would have reached a different conclusion. In other words, the panel must be very cautious in the manner in which it approaches and uses expert evidence, as the assistance provided by experts "is constrained by the kind of review that the panel is required to undertake". ${ }^{122}$ Its sole function is to determine whether the risk assessment has a valid scientific basis, regardless of its own opinion on its merits. In this case, the Appellate Body severely criticised the panel for its assessment, emphasizing that it had unduly reviewed the experts' opinions and "somewhat peremptorily decided what it considered to be the best science, rather than following the more limited exercise that its mandate required" ${ }^{123}$

However, no such standards can effectively be imposed on the ICJ and this paper can therefore do little more than to conclude by returning to its opening observations, namely that the fundamental differences in the structure of ICJ and WTO dispute settlement neutralize the value of any attempted comparison. The fact remains that both are built and operate on different grounds, and the more active recourse to ex curia experts in the WTO system cannot be reduced to the explanation of a more favourable disposition of the panels, nor can it therefore serve to relevantly criticize the practice of the ICJ and to positively inspire it to change its stance. In the end, this paper has undertaken to compare two judicial systems that are incomparable with respect to court-appointed experts, as the practice of WTO panels is largely determined by legal and institutional constraints of which the ICJ is free. Furthermore, when this precarious comparison touched ground on effectively comparable features, an examination of the practices revealed that behind the apparent discrepancy between both tribunals' approach to ex curia experts lay the same dubious tendencies of using their discretion and the textual gaps in their statutes to circumvent the appointment of independent experts. Finally, one should not forget that while the ICJ's avoidance of independent experts may undermine the cred-

120 Ibid., para. 592.

121 Ibid., para. 597.

122 Ibid., para. 592.

123 Ibid., para. 612. 
ibility and authority of certain judgments, and consequently its own, arguably WTO dispute settlement raises the same concern for the exact opposite reason, as it has increasingly appeared that proceedings are excessively science-driven. ${ }^{124}$ Between too little and too much expertise, the ICJ seems to err on the side of caution, which can certainly not be sustained lastingly without compromising its authority; on the other hand, the extent to which scientific discourse has pervaded WTO proceedings cannot but raise equal alarm, as it may have brought about, in the words of Lorenzo Gradoni:

[A] withdrawal of legal normativity which seems to correspond to a rise in power of experts, suppliers of an 'alternative' normativity. ${ }^{125}$

124 See Gradoni, supra note 12, 292, 312, who demonstrates that in many a case, the trier of the facts is, indeed, the expert. See also L. Gradoni, H. Ruiz Fabri, Laffaire des OGM devant le juge de l'OMC: science et précaution sans principes, 21 Diritto del commercio internazionale (2007), 641.

125 Ibid., 317. 
